\title{
Jackfruit Growing in the Florida Home Landscape ${ }^{1}$
}

\author{
Jonathan H. Crane, Carlos F. Balerdi, and Ian Maguire ${ }^{2}$
}

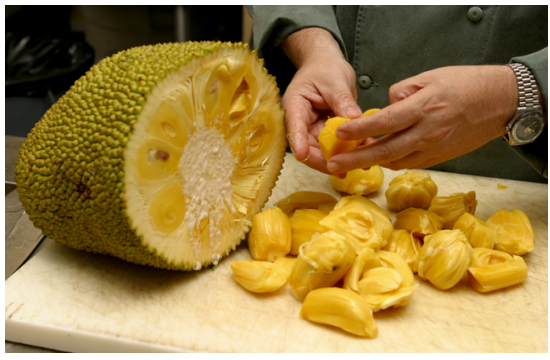

Jackfruit. Fig. 1. Cleaning a ripe jackfruit. Credits: Ian Maguire UF/IFAS/TREC

Scientific names: Artocarpus heterophyllus Lam.

Synonyms: Artocarpus integrifolius Auct.; A. integra Merr.

Other common names: English - jakfruit, jak; Spanish - jaca; Portuguese - jaca, jaqueira

Family: Moraceae

Relatives in the same family: Breadfruit (Artocarpus altilis), fig (Ficus sp.), mulberry (Morus sp.), champedak (A. integer), kwai muk (A. lingnanensis), Ficus benjamina.

Origin: Probably India
Distribution: India, Myanmar, Sri Lanka, China, Malaysia, Philippines, Australia, Kenya, Uganda, and Mauritius. Jackfruit is not widely cultivated but may be found in Brazil, Jamaica, the Bahamas, south Florida, and Hawaii.

Importance: Jackfruit is important in India and other Asian countries like Sri Lanka, southern China, Malaysia, Myanmar. There is limited production in Australia, Mauritius, Brazil, Surinam, Jamaica, Mexico, Hawaii and south Florida.

\section{Description}

Tree. Erect, evergreen, fairly large tree, 30 to 40 feet $(9-12 \mathrm{~m})$ tall in Florida.

Leaves. Dark green, alternate, glossy and somewhat leathery, fairly large and oval shaped on mature wood and deeply lobed on young shoots. All parts of the leaf contain a sticky white latex.

Flowers. Short, stout flowering twigs emerge from the trunk and large branches. The tree is monoecious (i.e., male and female flowers on the same tree) with small male flowers held by a thin

1. This document is HS882, one of a series of the Horticultural Sciences Department, Florida Cooperative Extension Service, Institute of Food and Agricultural Sciences, University of Florida. Original publication date November 2000. Revised October 2005. Visit the EDIS Web Site at http://edis.ifas.ufl.edu.

2. J.H. Crane, Professor and Tropical Fruit Crops Specialist, Tropical Research and Education Center, Homestead; C.F. Balerdi, Professor and Multicounty Tropical Fruit Crops Extension Agent; I. Maguire, Media Artist, Tropical Research and Education Center, Homestead; Cooperative Extension Service, Institute of Food and Agricultural Sciences, Miami-Dade County, Homestead.

The Institute of Food and Agricultural Sciences (IFAS) is an Equal Opportunity Institution authorized to provide research, educational information and other services only to individuals and institutions that function with non-discrimination with respect to race, creed, color, religion, age, disability, sex, sexual orientation, marital status, national origin, political opinions or affiliations. U.S. Department of Agriculture, Cooperative Extension Service, University of Florida, IFAS, Florida A. \& M. University Cooperative Extension Program, and Boards of County Commissioners Cooperating. Larry Arrington, Dean 


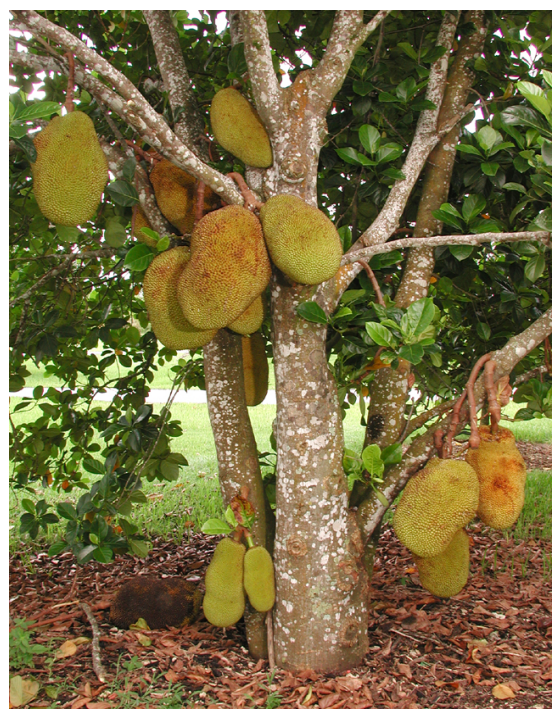

Jackfruit tree. Fig. 2. Seedling jackfruit tree. Credits: Ian Maguire UF/IFAS/TREC

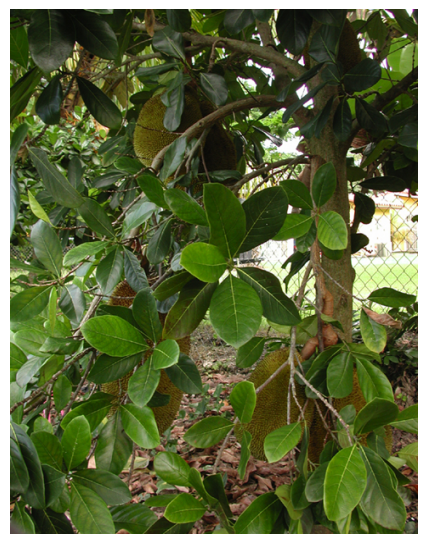

Jackfruit leaves. Fig. 3. Jackfruit leaves. Credits: Ian Maguire UF/IFAS/TREC

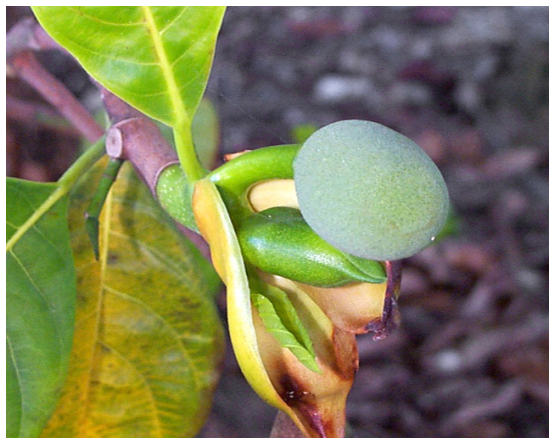

Jackfruit flowers. Fig. 4. Jackfruit flowers. Credits: Ian Maguire UF/IFAS/TREC

pedicel. Female flowers are larger than the males and the pedicel is quite thick.

Fruit. The jackfruit is a multiple fruit i.e., composed of the coherence of multiple flowers. Fruit is moderately large to very large, weighing from 10 to 60 pounds $(4.5-27.3 \mathrm{~kg})$. A few cultivars are small fruited, weighing 3 to 10 pounds $(1.4-4.5 \mathrm{~kg})$ each. The skin is extremely rough and thick. Fruit skin color is green when immature and green, greenish yellow to brownish-yellow when ripe. The inside of the fruit contains the edible, sweet, aromatic, crispy, soft or melting pulp that surrounds each seed. Between the seeds and edible pulp is the inedible "rag". Pulp color varies from amber to yellow, dark yellow or orange. Seeds are $3 / 4$ to $11 / 4$ inches $(2$ to $3 \mathrm{~cm})$ long, oval; the number per fruit varies from 30 to 500 . The time from flowering to fruit maturity ranges from 150 to 180 days.

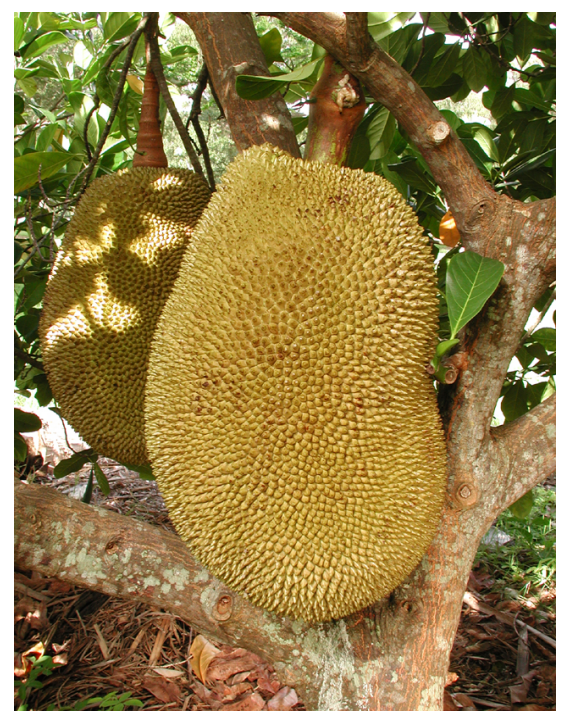

'Black gold' jackfruit. Fig. 5. 'Black Gold' jackfruit. Credits: Ian Maguire UF/IFAS/TREC

Season of bearing. The main fruiting season is in summer and fall. Some fruit may ripen at other times, but usually not in winter and early spring.

\section{Varieties}

There is limited experience on the performance of jackfruit cultivars under various conditions; however, initial evaluation of a number of cultivars has been completed (Table 1, Table 2). Homeowners should evaluate their fruit preferences carefully prior to selecting a tree for the landscape.

\section{Climate}

The jackfruit is well adapted to the hot humid tropics. Jackfruit grows well in the humid subtropical climate of south Florida along the coastal areas where there are only occasional freezes. Optimum growth and production occurs in continuously warm areas. 


\section{Drought Stress}

Jackfruit trees are moderately drought tolerant. However, for optimum tree growth and fruit production trees should be watered during dry periods.

\section{Flooding Stress}

Jackfruit trees are not tolerant of continuously wet and/or flooded soil conditions. Trees may decline or die after 2 to 3 days of wet soil conditions.

\section{Cold Stress}

Jackfruit leaves may be damaged at $32^{\circ} \mathrm{F}$ $\left(0^{\circ} \mathrm{C}\right)$, branches at $30^{\circ} \mathrm{F}\left(-1^{\circ} \mathrm{C}\right)$, and branches and trees may be killed at $28^{\circ} \mathrm{F}\left(-2^{\circ} \mathrm{C}\right)$.

\section{Wind Stress}

Jackfruit trees are tolerant of mild to moderately windy conditions. Trees survive and recover from hurricane force winds with some limb damage.

\section{Salt Stress}

There is only limited information of jackfruit tree tolerance to saline soil and/or water. Trees are probably not tolerant of saline conditions.

\section{Propagation}

Jackfruit may be propagated by seed, grafting, and cuttings. In some areas, seed propagation is still used. Jackfruit from seed may be more precocious than many other fruit, and trees may begin production in the $3^{\text {rd }}$ to $4^{\text {th }}$ year. Seeds should be collected from trees that have regular, high yields and that also have good horticultural characters, such as insect, disease and nematode resistance, proper fruit size and excellent pulp quality. Seeds are relatively short lived and may be stored up to about 30 days. In south Florida, seedlings and grafted trees are used.

If possible grafted trees of known cultivars are preferred. Seedlings of 'NS-1' and 'Black Gold' jackfruit have been used as rootstock sources. For rootstocks, select vigorously growing seedlings that are healthy and eliminate stunted, yellow or chlorotic seedlings. Chip budding, side veneer grafting, cleft grafting, and approach grafting have been used, but mostly side veneer grafting. Select scions or budsticks from trees growing vigorously, preferably in the summer or fall. Cut bud sticks 4 to 6 inches $(10-15 \mathrm{~cm})$ long from shoot tips, remove all the leaves, and be sure that the terminal bud is swollen. Budwood may be prepared ahead of time by removing the tip and then collecting the scions when buds begin to swell, after a week or two. Bud or graft trees when the rootstocks are about pencil size in diameter. The tip of the terminal bud should be left uncovered when veneer grafting. Place grafted trees in a mist bed in partial shade or cover with a plastic bag and place in the shade. Jackfruit can also be propagated by air layers, but this method is not commonly used.

Jackfruit trees are greatly affected by root restriction (i.e., being pot bound) and develop a deeper and stronger root system if planted in large, deep, long (18-24 inches; 45-61 cm), plastic pots. When planted, pot-bound trees do not establish well and grow poorly. Large jackfruit trees (2-4 feet tall; 0.6-1.2 m) establish more quickly and grow better when planted out than do small trees.

Cuttings are not a common propagation method for jackfruit, nor have plants propagated in this manner been tested under field conditions. However, semi-hardwood cuttings with 3 leaves (leaves cut in half across the midrib) dipped in 5,000 to $10,000 \mathrm{ppm}$ IBA ( $1 H$-indole-3-butanoic acid) and placed in an intermittent mist bed will root in about 60 to 70 days.

\section{Production (Crop Yields)}

Jackfruit are wind and insect pollinated and generally require cross-pollination for satisfactory fruit production. Thus, planting more than one cultivar may be of benefit. Mature jackfruit trees may produce from 40 to over 250 pounds $(18-114 \mathrm{~kg}$ ) per tree, depending on the cultivar, weather, and cultural practices. Trees that average 150 pounds $(68 \mathrm{~kg})$ per tree or more are considered good producers.

\section{Spacing}

At maturity, jackfruit trees not periodically pruned become large trees. If little or no pruning is planned then jackfruit in the home landscape should 
be planted 25 to 30 feet (7.6-9.1 m) away from other trees and structures. If annual or semi-annual pruning is practiced jackfruit trees may be planted 22 to 25 feet $(6.7-7.6 \mathrm{~m})$ away from other trees and structures. Trees planted too close to other trees or structures may not grow normally or produce much fruit due to shading.

\section{Soils}

Trees grow best in well-drained soils. Trees tolerate sand, sandy loams and the rocky, well-drained, high $\mathrm{pH}$, calcareous soils of southern Florida.

\section{Planting a Jackfruit Tree}

Planting may be done at anytime in south Florida provided there is access to water for the newly planted trees. Otherwise, the best time to plant is in late spring or early summer, early in the rainy season. Properly planting a jackfruit tree is one of the most important steps in successfully establishing and growing a strong, productive tree. The first step is to choose a healthy nursery tree. Commonly, nursery jackfruit trees are grown in 3 gallon containers and trees stand 2 to $4 \mathrm{ft}$ from the soil media. Large trees in smaller containers should be avoided as the root system may be "root bound". This means all the available space in the container has been filled with roots to the point that the tap root is growing along the edge of the container in a circular fashion. Root bound root systems may not grow properly once planted in the ground.

Inspect the tree for insect pests and diseases and inspect the trunk of the tree for wounds and constrictions. Select a healthy tree and water it regularly in preparation for planting in the ground.

\section{Site Selection}

In general, jackfruit trees should be planted in full sun for best growth and fruit production. Select a part of the landscape away from other trees, buildings and structures, and power lines. Remember jackfruit trees can become very large if not pruned to contain their size. Select the warmest area of the landscape that does not flood (or remain wet) after typical summer rainfall events.

\section{Planting in Sandy Soil}

Many areas in Florida have sany soil. Remove a 3 to $10 \mathrm{ft}(0.9-3.1 \mathrm{~m})$ diameter ring of grass sod. Dig a hole 3 to 4 times the diameter and 3 times a deep as the container the jackfruit tree has come in. Making a large hole loosens the soil adjacent to the new tree making it easy for the roots to expand into the adjacent soil. It is not necessary to apply fertilizer, topsoil, or compost to the hole. In fact, placing topsoil or compost in the hole first and then planting on top of it is not desirable. If you wish to add topsoil or compost to the native soil, mix it with the soil excavated from making the hole in no more than a 50-50 ratio.

Backfill the hole with some of the native soil removed to make the hole. Remove the tree from the container and place it in the hole so that the top of the soil media in the container is level with or slightly above the surrounding soil level. Fill soil in around the tree roots and tamp slightly to remove air pockets. Immediately water the soil around the tree and tree roots. Staking the tree with a wooden or bamboo stake is optional. However, do not use wire or nylon rope to tie the tree to the stake as they may eventually damage the tree trunk as it grows. Use a cotton or natural fiber string that will degrade slowly.

\section{Planting in Rockland Soil}

Many areas in Miami-Dade County have a very shallow soil and several inches below the soil surface is a hard calcareous bedrock. Remove a 3 to $10 \mathrm{ft}$ (0.9-3.1 m) diameter ring of grass sod. Make a hole 3 to 4 times the diameter and 3 times a deep as the container the jackfruit tree has come in. To dig a hole there are several options use a pick and digging bar to break up the rock or contract with a company that has augering equipment or a backhoe. Plant as described in the section above.

\section{Planting on a Mound}

Many areas in Florida are within $7 \mathrm{ft}(2.1 \mathrm{~m})$ or so of the water table and experience occasional flooding after heavy rainfall events. To improve plant survival consider planting fruit trees on a 2 to $3 \mathrm{ft}$ (0.6-0.9 $\mathrm{m})$ high by 4 to $10 \mathrm{ft}(1.2-3.1 \mathrm{~m})$ diameter mound of native soil. 
After the mound is made, dig a hole 3 to 4 times the diameter and 3 times a deep as the container the mango tree has come in. In areas where the bedrock nearly comes to the surface (rockland soil) follow the recommendations for the previous section. In areas with sandy soil follow the recommendations from the section on planting in sandy soil.

\section{Care of Jackfruit Trees in the Home Landscape}

A calendar outlining the month-to-month cultural practices for jackfruit is shown in Table 3.

\section{Fertilizer}

After planting when new growth begins, spread 1/4 lb. (113 g) of fertilizer, such as 6-6-6 with minor elements and $30 \%$ of the nitrogen from organic sources, per tree (Table 4). Repeat fertilizer applications every 6 to 8 weeks for the first year. Then, gradually increase the amount as the trees grow.

Apply 4 to 6-minor element (nutritional) sprays per tree per year, sprayed on the foliage from April to September. For trees in acid to neutral soils apply iron sulfate at 0.25 to $1 \mathrm{oz}$ per tree to the soil 2 to 4 timers per year. Apply a soil drench of chelated iron once or twice per year per tree from June through September. For calcareous soils use EDDHA (technical sodium ferric ethylenediamine di-(o-hydroxyphenylacetate) iron chelate, and for neutral and acid soils use EDTHA (technical sodium ferric diethylenetriamine pentaacetate) iron chelate.

For mature trees, fertilizer should be applied 2 to 3 times from bloom to right after harvesting and pruning. Iron applications are most effective from May to September, and foliar sprays from April to September.

\section{Irrigation (Watering)}

A means of watering young trees should be available for newly planted and young trees. Regular watering during dry periods is recommended for newly planted and young trees. For mature trees watering is recommended during dry periods and is critical from bloom through fruit development.

\section{Insect Pests}

There are a number of wood boring insects that may attack wounded or dead wood along the trunks and branches (Elaphidion mucronatum, Nyssodrysina haldemani, Leptostylopsis terraecolor). Various scales such as the lesser snow scale (Pinnaspis strachani), coconut scale (Aspidiotus destructor), mango shield scale (Protopulvinaria mangiferae), pyriform scale (Protopulvinaria pyrifomis) and mealybugs may attack stems and fruit. Please contact your local Agricultural Extension Agent for current control options.

\section{Diseases}

In general, jackfruit have few disease problems in south Florida. Male flowers and fruit may be attacked by Rhizopus fruit rot (Rhizopus artocarpi) and fruit by gray mold (Botrytis cinerea). Trees are susceptible to root rot (Pythium splendens, Phytophthora sp., Fusarium sp., Rhizoctonia sp.) especially when subjected to flooding. Several fungi (i.e., Gloeosporium sp., Phyllosticta artocarpi) cause leaf spotting. Please contact your local Agricultural Extension Agent for current control options.

\section{Weed Control}

Weeds compete for water and nutrients and may slow tree establishment. After planting, keep grass away from the tree trunk.

\section{Jackfruit Trees and Lawn Care}

Jackfruit trees in the home landscape are susceptible to trunk injury caused by lawn mowers and weed eaters. Maintain a grass-free area 2 to 5 or more away from the trunk of the tree. Never hit the tree trunk with lawn mowing equipment and never use a weed eater near the tree trunk. Mechanical damage to the trunk of the tree will result in weakening the tree and if severe enough can cause the tree to dieback or die.

Roots of mature jackfruit trees spread beyond the drip-line of the tree canopy and heavy fertilization of the lawn adjacent to jackfruit trees is not recommended and may reduce fruiting and or fruit 
quality. The use of lawn sprinkler systems on a timer may result in over watering and cause jackfruit trees to decline. This is because too much water, too often is being applied which results in root rot.

\section{Mulch}

Mulching jackfruit trees in the home landscape helps retain soil moisture, reduces weed problems adjacent to the tree trunk, and improves the soil near the surface. Mulch with a 2 to 6 inch $(5-15 \mathrm{~cm})$ layer of bark, wood chips, or similar mulch material. Keep mulch 8 to 12 inches $(20-30 \mathrm{~cm})$ from the trunk.

\section{Pruning}

Young trees. Young jackfruit trees do not need pruning during their first year. Shoot tip pruning once or twice during spring and summer will force lateral bud break and make the tree more compact. Non-pruned trees usually develop a strong central leader. During the second season, trees should be pruned to the first lateral branch, which will slow upward growth and enhance spreading of the canopy. As trees mature, upright vigorous shoots should be removed and the inner canopy thinned out at the end of the harvest season.

Mature trees. Removal of selected upright, vigorously growing shoots is recommended.

Removing the central leader to a weak lateral branch will slow upward growth and enhance lateral canopy development. Old flowering shoots should be removed after harvest.

For bearing trees, periodically remove (thin out) old limbs at the end of the harvest season to increase light penetration to the inner canopy. Tree height may be maintained at 8 to 14 feet by periodic selective pruning. Selective pruning may also be used to limit tree width.

Fruit thining. The number of fruit per tree or major limb should be limited to 1 on young trees, as heavy fruit loads have been observed to result in limb decline or death and tree stunting. On mature trees, limiting the number of fruit per major limb may enhance the quality and size of remaining fruit.

\section{Harvest, Ripening, and Storage}

Jackfruit may be eaten as a vegetable when picked at an immature stage or eaten fresh when picked at a mature stage and allowed to ripen. Immature fruit is usually 1 to 3 months old, are green and may be harvested for cooking.

Mature fruit have 35 to $40 \%$ edible flesh. However, it is not easy to determine when the fruit is ripe. There are several fruit characteristics that may be used alone or together indicate a particular cultivar is mature. In many cultivars the skin color changes from green to light green or yellow. Maturing fruits usually develop a strong aroma and the peel spines flatten and widen. Green fruits have a solid sound when tapped whereas ripe fruits have a hollow sound.

Harvest fruit with clippers or loppers. The cut stem will immediately exude white, sticky latex; this latex will permanently stain clothing. Wrap the cut end with a paper towel to make handling easier, or set the fruit on its side until the flow of latex ceases. Care should be exercised not to let the fruit drop to the ground and be damaged. Pickers may want to wear gloves when handling the fruit. Place fruit in the shade until the latex stops exuding from the cut stem.

Mature fruit will ripen in 3 to 10 days at $75^{\circ} \mathrm{F}$ to $80^{\circ} \mathrm{F}\left(24-27^{\circ} \mathrm{C}\right)$. Before consumption the edible flesh is separated from the rag. As with harvesting, latex may exude from cut surfaces when extracting the flesh. To make clean-up easier coat hands, knife blades (not the handle), and work surfaces with vegetable oil. To clean the fruit, cut in half and remove the central core; then proceed to separate the flesh, seed, and rag.

Cool temperatures $\left(<60^{\circ} \mathrm{F} ; 16^{\circ} \mathrm{C}\right)$ may delay ripening. The proper storage temperatures for jackfruit have not been determined. Fruit pulp may be stored in the refrigerator and fully ripe fruit segments may be placed in polyethylene bags and frozen for later use. 


\section{Uses and Nutritional Value}

Jackfruit have a number of uses. Green, immature fruit may be used as a vegetable in cooking including soups, and baked dishes, and fried. The pulp of ripe fruit may be eaten fresh, dried, or preserved in syrup or used for salads. The seeds can be boiled and roasted (eaten as a nut) and have a chestnut flavor. Jackfruit is low in calories and fat and a good source of potassium and Vitamin A (Table $5)$. 
Table 1. Characteristics of jackfruit varieties.

\begin{tabular}{|c|c|c|c|c|c|c|c|}
\hline $\begin{array}{c}\text { Cultivar } \\
\text { and origin }\end{array}$ & $\begin{array}{l}\text { Growth habit } \\
\text { and rate }\end{array}$ & $\begin{array}{c}\text { Fruit size } \\
\text { and weight } \\
\text { (lbs) }\end{array}$ & $\begin{array}{l}\text { Fruit } \\
\text { shape }\end{array}$ & $\begin{array}{l}\text { Yield per } \\
\text { tree (lbs) }\end{array}$ & $\begin{array}{c}\text { Season } \\
\text { and months }\end{array}$ & Photo & Comments \\
\hline $\begin{array}{l}\text { Black } \\
\text { Gold, } \\
\text { Australia }\end{array}$ & $\begin{array}{l}\text { Open, } \\
\text { spreading, } \\
\text { fast }\end{array}$ & $\begin{array}{l}\text { Medium, } \\
22\end{array}$ & $\begin{array}{l}\text { Long, } \\
\text { tapered }\end{array}$ & $\begin{array}{l}\text { Heavy, } \\
120-200\end{array}$ & $\begin{array}{l}\text { Late, } \\
\text { Sept.-Oct. }\end{array}$ & Photo & $\begin{array}{l}\text { Tree easily pruned to } \\
\text { maintain small tree }(\sim 8 \mathrm{ft})\end{array}$ \\
\hline $\begin{array}{l}\text { Cheena, } \\
\text { Australia }\end{array}$ & $\begin{array}{l}\text { Open, low } \\
\text { spreading, } \\
\text { moderate }\end{array}$ & Small, 5-10 & $\begin{array}{l}\text { Long, } \\
\text { narrow, } \\
\text { uniform }\end{array}$ & $\begin{array}{l}\text { Moderately } \\
\text { heavy, } \\
110-154\end{array}$ & $\begin{array}{l}\text { Mid, } \\
\text { July-Aug. }\end{array}$ & & $\begin{array}{l}\text { Hybrid with champedak (A. } \\
\text { integer); tree easily pruned } \\
\text { to maintain small tree ( } 8 \\
\text { ft) }\end{array}$ \\
\hline $\begin{array}{l}\text { Chompa } \\
\text { Gob }\end{array}$ & $\begin{array}{l}\text { Open, } \\
\text { spreading, } \\
\text { fast }\end{array}$ & $\begin{array}{l}\text { Medium, } \\
12-20\end{array}$ & $\begin{array}{l}\text { Blocky, } \\
\text { uniform }\end{array}$ & $\begin{array}{l}\text { Moderately } \\
\text { heavy, } \\
90-120\end{array}$ & $\begin{array}{l}\text { Mid, } \\
\text { July-Aug. }\end{array}$ & & $\begin{array}{l}\text { Easily pruned to maintain } \\
\text { small tree size }\end{array}$ \\
\hline $\begin{array}{l}\text { Cochin, } \\
\text { Australia }\end{array}$ & $\begin{array}{l}\text { Sparse, } \\
\text { upright, slow }\end{array}$ & Small, 2-5 & $\begin{array}{l}\text { Round, } \\
\text { irregular }\end{array}$ & $\begin{array}{l}\text { Moderately } \\
\text { heavy, } \\
80-130\end{array}$ & $\begin{array}{l}\text { Early, } \\
\text { June-July }\end{array}$ & & $\begin{array}{l}\text { Thinning the number of fruit } \\
\text { recommended; tree easily } \\
\text { pruned to maintain small } \\
\text { tree }(\sim 8 \mathrm{ft})\end{array}$ \\
\hline $\begin{array}{l}\text { Dang } \\
\text { Rasimi, } \\
\text { Thailand }\end{array}$ & $\begin{array}{l}\text { Open, } \\
\text { spreading, } \\
\text { fast }\end{array}$ & $\begin{array}{l}\text { Medium- } \\
\text { large, } \\
18-20\end{array}$ & $\begin{array}{l}\text { Uniform } \\
\text { oblong }\end{array}$ & $\begin{array}{l}\text { Very } \\
\text { heavy, } \\
165-275\end{array}$ & $\begin{array}{l}\text { Mid, } \\
\text { July-Aug. }\end{array}$ & & $\begin{array}{l}\text { Vigorous tree; annual } \\
\text { pruning needed to maintain } \\
\text { moderate size }(\sim 11 \mathrm{ft})\end{array}$ \\
\hline $\begin{array}{l}\text { Gold } \\
\text { Nugget, } \\
\text { Australia }\end{array}$ & $\begin{array}{l}\text { Dense, } \\
\text { spreading, } \\
\text { fast }\end{array}$ & Small, 7-12 & Round & $\begin{array}{l}\text { Heavy, } \\
132-176\end{array}$ & $\begin{array}{l}\text { Early, } \\
\text { May-June }\end{array}$ & Photo & $\begin{array}{l}\text { Thinning number of fruit } \\
\text { recommended; tree easily } \\
\text { pruned to maintain small } \\
\text { tree }(\sim 8 \mathrm{ft})\end{array}$ \\
\hline $\begin{array}{l}\text { Honey } \\
\text { Gold, } \\
\text { Australia }\end{array}$ & $\begin{array}{l}\text { Sparse, } \\
\text { spreading, } \\
\text { slow- } \\
\text { moderate }\end{array}$ & $\begin{array}{l}\text { Small to } \\
\text { medium- } \\
\text { small, } \\
10-12\end{array}$ & Blocky & $\begin{array}{l}\text { Moderate, } \\
77-110\end{array}$ & $\begin{array}{l}\text { Mid, } \\
\text { July-Aug. }\end{array}$ & & $\begin{array}{l}\text { Thinning number of fruit } \\
\text { recommended; tree easily } \\
\text { pruned to maintain small } \\
\text { tree }(\sim 8 \mathrm{ft})\end{array}$ \\
\hline $\begin{array}{l}\text { J-30, } \\
\text { Malaysia }\end{array}$ & $\begin{array}{l}\text { Vigorous, } \\
\text { open, conical, } \\
\text { fast }\end{array}$ & $\begin{array}{l}\text { Medium, } \\
17-25\end{array}$ & $\begin{array}{l}\text { Uniform, } \\
\text { oblong }\end{array}$ & $\begin{array}{l}\text { Moderately } \\
\text { heavy, } \\
110-132\end{array}$ & $\begin{array}{l}\text { Mid, } \\
\text { July-Aug. }\end{array}$ & & $\begin{array}{l}\text { Vigorous tree; annual } \\
\text { pruning needed to maintain } \\
\text { moderate size }(\sim 10 \mathrm{ft})\end{array}$ \\
\hline $\begin{array}{l}\text { J-31, } \\
\text { Malaysia }\end{array}$ & $\begin{array}{l}\text { Open, } \\
\text { spreading, } \\
\text { fast }\end{array}$ & Large, 26 & Irregular & $\begin{array}{l}\text { Moderately } \\
\text { heavy, } \\
92-132\end{array}$ & $\begin{array}{l}\text { Early, } \\
\text { May-June }\end{array}$ & & $\begin{array}{l}\text { Often off-season fruit; tree } \\
\text { easily pruned to maintain } \\
\text { small tree }(\sim 8 \mathrm{ft})\end{array}$ \\
\hline $\begin{array}{l}\text { Kun Wi } \\
\text { Chan, } \\
\text { Thailand }\end{array}$ & $\begin{array}{l}\text { Vigorous, } \\
\text { dense, fast }\end{array}$ & $\begin{array}{l}\text { Large, } \\
33-40\end{array}$ & $\begin{array}{l}\text { Uniform, } \\
\text { round }\end{array}$ & $\begin{array}{l}\text { Very } \\
\text { heavy, } \\
242\end{array}$ & $\begin{array}{l}\text { Mid, } \\
\text { July-Aug. }\end{array}$ & Photo & $\begin{array}{l}\text { Vigorous tree; annual } \\
\text { pruning needed to maintain } \\
\text { moderate size }(\sim 13 \mathrm{ft})\end{array}$ \\
\hline $\begin{array}{l}\text { Lemon } \\
\text { Gold, } \\
\text { Australia }\end{array}$ & $\begin{array}{l}\text { Moderately } \\
\text { dense, } \\
\text { spreading, } \\
\text { moderate }\end{array}$ & $\begin{array}{l}\text { Medium- } \\
\text { small, } 13\end{array}$ & Blocky & $\begin{array}{l}\text { Moderate, } \\
66-100\end{array}$ & $\begin{array}{l}\text { Mid, } \\
\text { July-Aug. }\end{array}$ & & $\begin{array}{l}\text { Vigorous tree; annual } \\
\text { pruning needed to maintain } \\
\text { moderate size }(\sim 12 \mathrm{ft})\end{array}$ \\
\hline
\end{tabular}


Table 1. Characteristics of jackfruit varieties.

\begin{tabular}{||l|l|l|l|l|l|l|l}
\hline \hline $\begin{array}{l}\text { NS1, } \\
\text { Malaysia }\end{array}$ & $\begin{array}{l}\text { Dense, } \\
\text { upright, } \\
\text { moderate }\end{array}$ & $\begin{array}{l}\text { Small to } \\
\text { medium- } \\
\text { small, 9-12 }\end{array}$ & Blocky & $\begin{array}{l}\text { Heavy, } \\
200\end{array}$ & $\begin{array}{l}\text { Early, } \\
\text { May-June }\end{array}$ & $\begin{array}{l}\text { Thinning number of fruit } \\
\text { recommended for young } \\
\text { trees; moderately vigorous } \\
\text { tree; annual pruning to } \\
\text { maintain moderate size ( 10 } \\
\mathrm{ft})\end{array}$ \\
\hline $\begin{array}{l}\text { Tabouey, } \\
\text { Indonesia }\end{array}$ & $\begin{array}{l}\text { Open, } \\
\text { rounded, } \\
\text { slow- } \\
\text { moderate }\end{array}$ & $\begin{array}{l}\text { Medium- } \\
\text { large to } \\
\text { large, } \\
20-25\end{array}$ & $\begin{array}{l}\text { Long, } \\
\text { tapered }\end{array}$ & $\begin{array}{l}\text { Moderately } \\
\text { heavy, } \\
110-154\end{array}$ & $\begin{array}{l}\text { Late, } \\
\text { Sept.-Oct. }\end{array}$ & $\begin{array}{l}\text { Thinning number of fruit } \\
\text { recommended for young } \\
\text { trees; moderately vigorous } \\
\text { tree; annual pruning to } \\
\text { maintain moderate size ( 10 } \\
\mathrm{ft})\end{array}$ \\
\hline \hline
\end{tabular}

Table 2. Pulp characteristics of jackfruit varieties.

\begin{tabular}{|c|c|c|c|c|c|c|c|}
\hline Cultivar & Color & Texture & $\begin{array}{l}\text { Flat spines } \\
\text { at ripening }\end{array}$ & $\begin{array}{l}\% \text { edible } \\
\text { flesh }\end{array}$ & $\begin{array}{c}\text { \# seeds } \\
\text { per fruit; } \\
\text { seed } \%\end{array}$ & Quality & Comments \\
\hline $\begin{array}{l}\text { Black } \\
\text { Gold }\end{array}$ & $\begin{array}{l}\text { Deep } \\
\text { orange }\end{array}$ & $\begin{array}{l}\text { Medium-firm } \\
\text { to melting, } \\
\text { soft }\end{array}$ & No & 35 & $192 ; 17$ & $\begin{array}{l}\text { Good, } \\
\text { sweet, } \\
\text { aromatic }\end{array}$ & $\begin{array}{l}\text { Flesh easily } \\
\text { removed }\end{array}$ \\
\hline Cheena & $\begin{array}{l}\text { Deep } \\
\text { orange }\end{array}$ & $\begin{array}{l}\text { Soft, melting, } \\
\text { somewhat } \\
\text { fibrous }\end{array}$ & Yes & 33 & $38 ; 11$ & $\begin{array}{l}\text { Excellent, } \\
\text { very } \\
\text { aromatic }\end{array}$ & $\begin{array}{l}\text { Flesh easily } \\
\text { removed }\end{array}$ \\
\hline Cochin & $\begin{array}{l}\text { Yellow to } \\
\text { orange }\end{array}$ & $\begin{array}{l}\text { Firm to } \\
\text { crunchy }\end{array}$ & Yes & $35-50$ & $35 ; 7$ & $\begin{array}{l}\text { Good, } \\
\text { mild }\end{array}$ & $\begin{array}{l}\text { Sometimes "rag" } \\
\text { edible }\end{array}$ \\
\hline $\begin{array}{l}\text { Chompa } \\
\text { Gob }\end{array}$ & Orange & Firm & Yes & 30 & $200 ; 7$ & $\begin{array}{l}\text { Good, mild } \\
\text { flavor }\end{array}$ & $\begin{array}{l}\text { Texture of } \\
\text { excellent quality }\end{array}$ \\
\hline $\begin{array}{l}\text { Dang } \\
\text { Rasimi }\end{array}$ & $\begin{array}{l}\text { Deep } \\
\text { orange }\end{array}$ & Firm to soft & No & 32 & $187 ; 12$ & $\begin{array}{l}\text { Mild, sweet } \\
\text { flavor, } \\
\text { pleasant } \\
\text { aroma }\end{array}$ & Flesh thin walled \\
\hline $\begin{array}{l}\text { Golden } \\
\text { Nugget }\end{array}$ & $\begin{array}{l}\text { Deep } \\
\text { orange }\end{array}$ & $\begin{array}{l}\text { Soft to } \\
\text { medium firm }\end{array}$ & Yes & 41 & $79 ; 13$ & $\begin{array}{l}\text { Excellent } \\
\text { flavor }\end{array}$ & $\begin{array}{l}\text { Fruit may split after } \\
\text { heavy rains }\end{array}$ \\
\hline $\begin{array}{l}\text { Honey } \\
\text { Gold }\end{array}$ & $\begin{array}{l}\text { Dark } \\
\text { yellow to } \\
\text { orange }\end{array}$ & Firm & Yes & 36 & $42 ; 5$ & $\begin{array}{l}\text { Sweet, rich } \\
\text { flavor and } \\
\text { aroma }\end{array}$ & $\begin{array}{l}\text { Flesh thick walled, } \\
\text { excellent texture }\end{array}$ \\
\hline $\mathrm{J}-30$ & $\begin{array}{l}\text { Deep } \\
\text { orange }\end{array}$ & Firm & Yes & 38 & $200 ; 9$ & $\begin{array}{l}\text { Sweet rich } \\
\text { flavor and } \\
\text { aroma }\end{array}$ & $\begin{array}{l}\text { Flesh thick walled, } \\
\text { excellent texture }\end{array}$ \\
\hline$J-31$ & $\begin{array}{l}\text { Deep } \\
\text { yellow }\end{array}$ & Firm & Yes & 36 & $180 ; 18$ & $\begin{array}{l}\text { Sweet rich } \\
\text { flavor, } \\
\text { earthy } \\
\text { aroma }\end{array}$ & $\begin{array}{l}\text { Fruit rarely splits, } \\
\text { excellent texture }\end{array}$ \\
\hline
\end{tabular}


Table 2. Pulp characteristics of jackfruit varieties.

\begin{tabular}{||l|l|l|l|l|l|l|l||}
\hline \hline $\begin{array}{l}\text { Kun Wi } \\
\text { Chan }\end{array}$ & Yellow & $\begin{array}{l}\text { Moderately } \\
\text { firm to soft }\end{array}$ & No & 29 & $210 ; 11$ & $\begin{array}{l}\text { Mild, } \\
\text { pleasant } \\
\text { flavor }\end{array}$ & $\begin{array}{l}\text { Generally } \\
\text { considered of } \\
\text { mediocre quality }\end{array}$ \\
\hline $\begin{array}{l}\text { Lemon } \\
\text { Gold }\end{array}$ & $\begin{array}{l}\text { Lemon } \\
\text { yellow }\end{array}$ & Firm & Yes & 37 & $104 ; 14$ & $\begin{array}{l}\text { Sweet and } \\
\text { aromatic } \\
\text { flavor }\end{array}$ & Flesh thick walled \\
\hline NS1 & $\begin{array}{l}\text { Dark } \\
\text { orange }\end{array}$ & Firm & Yes & 34 & $63 ; 5$ & $\begin{array}{l}\text { Sweet rich } \\
\text { flavor }\end{array}$ & Excellent texture \\
\hline Tabouey & $\begin{array}{l}\text { Light } \\
\text { yellow }\end{array}$ & Firm & No & 40 & $250 ; 12$ & $\begin{array}{l}\text { Mild, } \\
\text { pleasant } \\
\text { flavor, very } \\
\text { little } \\
\text { aroma }\end{array}$ & $\begin{array}{l}\text { Fruit may split, } \\
\text { often irregular }\end{array}$ \\
\hline \hline
\end{tabular}




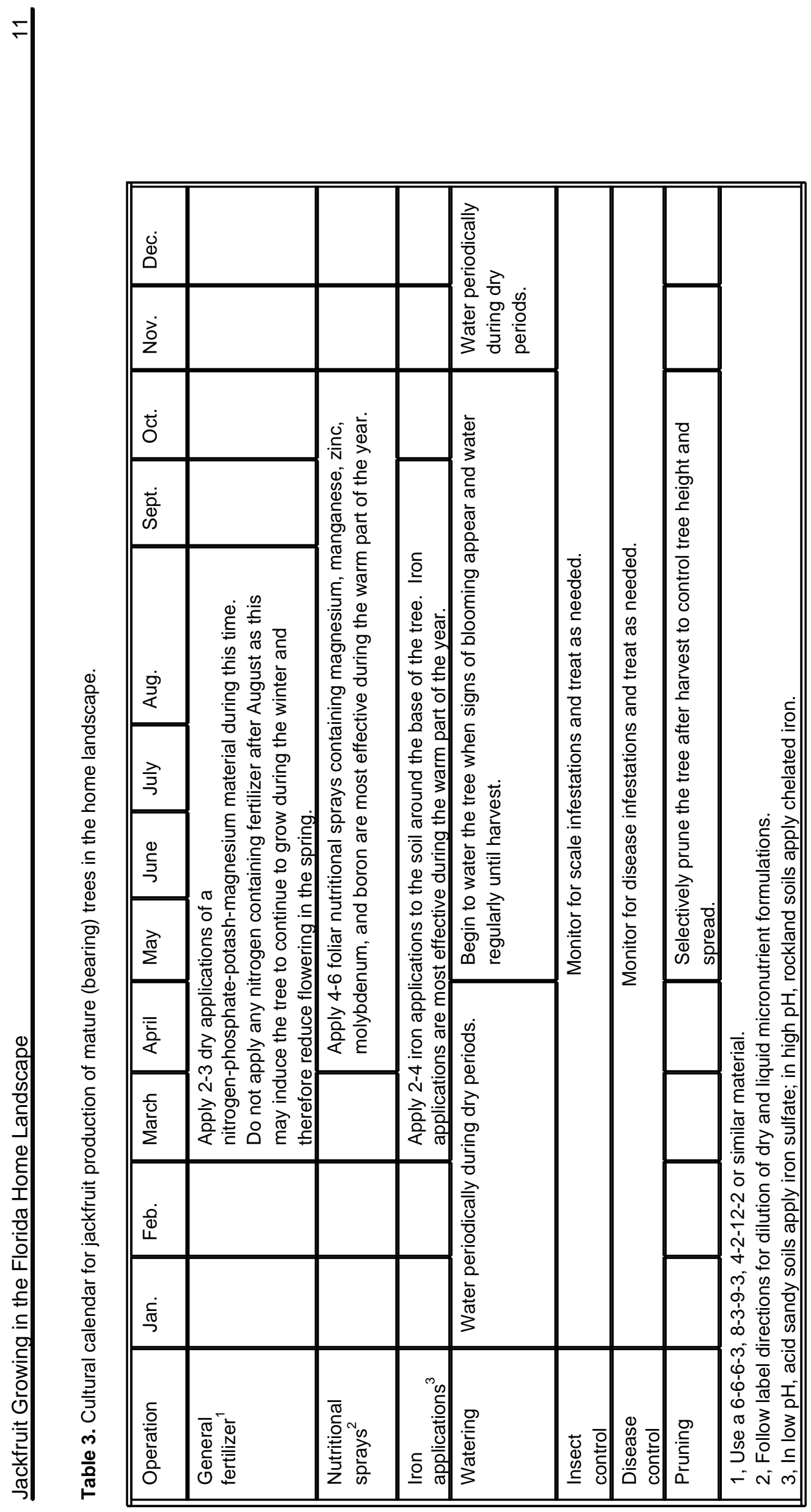


Table 4. Fertilizer recommendations for jackfruit in Florida.

\begin{tabular}{|c|c|c|c|c|c|}
\hline Year & $\begin{array}{l}\text { Times } \\
\text { per year }\end{array}$ & $\begin{array}{l}\text { Amount per } \\
\text { tree (lbs) }^{1}\end{array}$ & $\begin{array}{c}\text { Total } \\
\text { amount per } \\
\text { tree (lbs) }\end{array}$ & $\begin{array}{l}\text { No. of minor } \\
\text { element sprays } \\
\text { per year }^{3}\end{array}$ & $\begin{array}{l}\text { Chelated iron } \\
\text { soil drenches } \\
\text { (oz/tree/year) }^{4}\end{array}$ \\
\hline 1 & 6 & $0.25-0.5$ & $1.5-3.0$ & 6 & $0.5-0.75$ \\
\hline 2 & 6 & $0.5-1.0$ & $3.0-6.0$ & 6 & $0.75-1.0$ \\
\hline 3 & 6 & $1.0-1.5$ & $6.0-9.0$ & 6 & $1.0-1.5$ \\
\hline 4 & $2-3$ & $1.5-2.5$ & $9.0-10.0$ & 6 & $1.5-2$ \\
\hline 5 & $2-3$ & $2.5-3.5$ & $10.0-14.0$ & $4-6$ & $2-4$ \\
\hline 6 & $2-3$ & $3.5-4.0$ & $14.0-16.0$ & $4-6$ & $2-4$ \\
\hline 7 & $2-3$ & $4.0-4.5$ & $16.0-18.0$ & $4-6$ & $2-4$ \\
\hline 8 & $2-3$ & $4.5-5$ & $18.0-20.0$ & $4-6$ & $2-4$ \\
\hline \multicolumn{6}{|c|}{$\begin{array}{l}\text { 1, Amount of NPK per tree per application. Use 6-6-6 or 8-3-9 or slow release fertilizer material. } \\
\text { 2, Total amount per tree per year. } \\
\text { 3, Foliar sprays should contain zinc, manganese, boron, molybedenum, and possibly magnesium. } \\
\text { 4, Chelated iron soil drenches may prevent iron deficiency. Foilar iron sprays are not generally } \\
\text { effective. }\end{array}$} \\
\hline
\end{tabular}

Table 5. Nutrient value of $100 \mathrm{~g}$ (3.5 oz) of fresh jackfruit.

\begin{tabular}{||l|l|l|c||}
\hline \hline Constituent & $\begin{array}{l}\text { Approximate } \\
\text { value }\end{array}$ & Constituent & $\begin{array}{l}\text { Approximate } \\
\text { value }\end{array}$ \\
\hline $\begin{array}{l}\text { Water } \\
\text { content }\end{array}$ & $73 \%$ & Iron & $0.6 \mathrm{mg}$ \\
\hline Calories & $94 \mathrm{kcal}$ & Magnesium & $37.0 \mathrm{mg}$ \\
\hline Protein & $1.5 \mathrm{~g}$ & Phosphorus & $36.0 \mathrm{mg}$ \\
\hline Fat & $0.3 \mathrm{~g}$ & Potassium & $303.0 \mathrm{mg}$ \\
\hline Cholesterol & $0 \mathrm{~g}$ & Sodium & $3.0 \mathrm{mg}$ \\
\hline Carbohydrate & $24.0 \mathrm{~g}$ & Vitamin C & $6.7 \mathrm{mg}$ \\
\hline \hline
\end{tabular}


Table 5. Nutrient value of $100 \mathrm{~g}$ (3.5 oz) of fresh jackfruit.

\begin{tabular}{||l|l|l|c||}
\hline \hline $\begin{array}{l}\text { Total dietary } \\
\text { fiber }\end{array}$ & $1.6 \mathrm{~g}$ & Vitamin A & $297 \mathrm{IU}$ \\
\hline \hline
\end{tabular}

